\title{
Optimization of HILIC method for the analysis of bisoprolol and its impurities considering uncertainties in peak position
}

\section{Tijana Rakić $^{1 *}$, Marko Jovanović ${ }^{1}$, Anja Tumpa ${ }^{1}$, Biljana Jančić-Stojanović ${ }^{1}$, Mirjana Medenica ${ }^{2}$}

${ }^{1}$ University of Belgrade - Faculty of Pharmacy, Department of Drug Analysis, Vojvode Stepe 450, Belgrade, Serbia

${ }^{2}$ University of Belgrade - Faculty of Pharmacy, Department of Physical Chemistry and Instrumental Methods, Vojvode Stepe 450, Belgrade, Serbia

*corresponding author: Phone: +381 113951 333; email:tijana.rakic@pharmacy.bg.ac.rs

\section{Summary}

This paper presents the robust optimization of hydrophilic interaction liquid chromatographic method for the analysis of bisoprolol and its impurities A and C. Chemometric strategy is applied for detailed understanding of system's behavior and establishing the mathematical relationship between investigated factors (acetonitrile content in the mobile phase, $\mathrm{pH}$ of the water phase and buffer concentration in the water phase) and chromatographic responses. Grid point search methodology is then performed with the aim to identify the point with satisfactory separation quality for all analyzed substances and to achieve minimal analysis duration. Oversized chromatograms are made creating an extra band broadening for each chromatographic peak corresponding to the value of standard deviation in order to evaluate the incertitude originating from the model uncertainty. On the other hand, the uncertainty originating from the variation of experimental parameters is assessed by simulated experimental design robustness testing. Finally, the obtained robust optimal conditions were: chromatographic column Kinetex HILIC $100 \AA$ (100 mm x $4.5 \mathrm{~mm}, 2.6 \mu \mathrm{m}$ particle size); mobile phase composed of acetonitrile - water phase $(35 \mathrm{mM}$ ammonium acetate, $\mathrm{pH} 4.9$ adjusted with glacial acetic acid) $(85: 15 \mathrm{v} / \mathrm{v})$; flow rate $1 \mathrm{~mL} \mathrm{~min}^{-1}$, column temperature $30{ }^{\circ} \mathrm{C}$ and UV detection at $254 \mathrm{~nm}$.

Keywords: robust optimization, HILIC, bisoprolol, impurities 


\section{Introduction}

Science based approach to liquid chromatographic (LC) method development includes thorough understanding of method performances under different conditions, systematic incorporation of quality into the method and full control over all possible negative outcomes. Therefore, chemometric techniques have been widely used for LC method developments in scientific literature [1]. However, the interest for them is rising constantly in pharmaceutical practice and industry, mainly, due to the introduction of recent regulations (ICH Q8 [2], ICH Q9 [3] and ICH Q10 [4]). Applying sophisticated mathematical, statistical and computational skills analysts are challenged to create as best methods as possible in terms of various desired quality characteristic. The core idea of the process is mathematical description of the system behavior establishing the accurate relationship between important method parameters and desired goals and subsequent theoretical examination of the experimental space. In the majority of cases, the most important LC method targets are the achievement of maximal separation quality within minimal analysis duration. However, recent trends in pharmaceutical analysis emphasize the importance of robustness issue in early phases of the method development since the identified optimum is completely useless if its quality cannot be preserved during experimental procedure [5-7].

Robust optimization leads to the creation of LC methods which are more reliable and therefore the risk for method failure in the validation phase is significantly decreased. It can be considered as a "pre-validation" since it mimics the robustness testing procedure in the validation phase but with significant saving of money and time [5]. The robust optimum should preserve desired quality level while slight variations in defined experimental conditions are performed simulating the expected uncertainty in adjustment of method parameters. However, the accuracy and stability of defined optimum depends also on the accuracy of the created mathematical relationship that describes optimum's dependence on investigated factors [6].

This paper will present the robust optimization of hydrophilic interaction liquid chromatographic (HILIC) method for the analysis of bisoprolol and its impurities taking into consideration two important sources of optimum uncertainty: the one originating from the mathematical model uncertainty and the other originating from the incertitude in adjustment of method's parameters.

Pharmaceutical analysis shows increasing interest in HILIC since it is especially suitable for the analysis of the group of polar ionisable compounds, such are numerous pharmaceutically active compounds [8-9]. Method development in this type of chromatography is challenging due to the complex retention mechanism that is not yet well explained in the literature. Moreover, this system is very sensitive to the slight 
changes in experimental conditions making the issue of robust optimization even more complicated.

The chemical structure of bisoprolol and investigated impurities is presented in Figure 1.
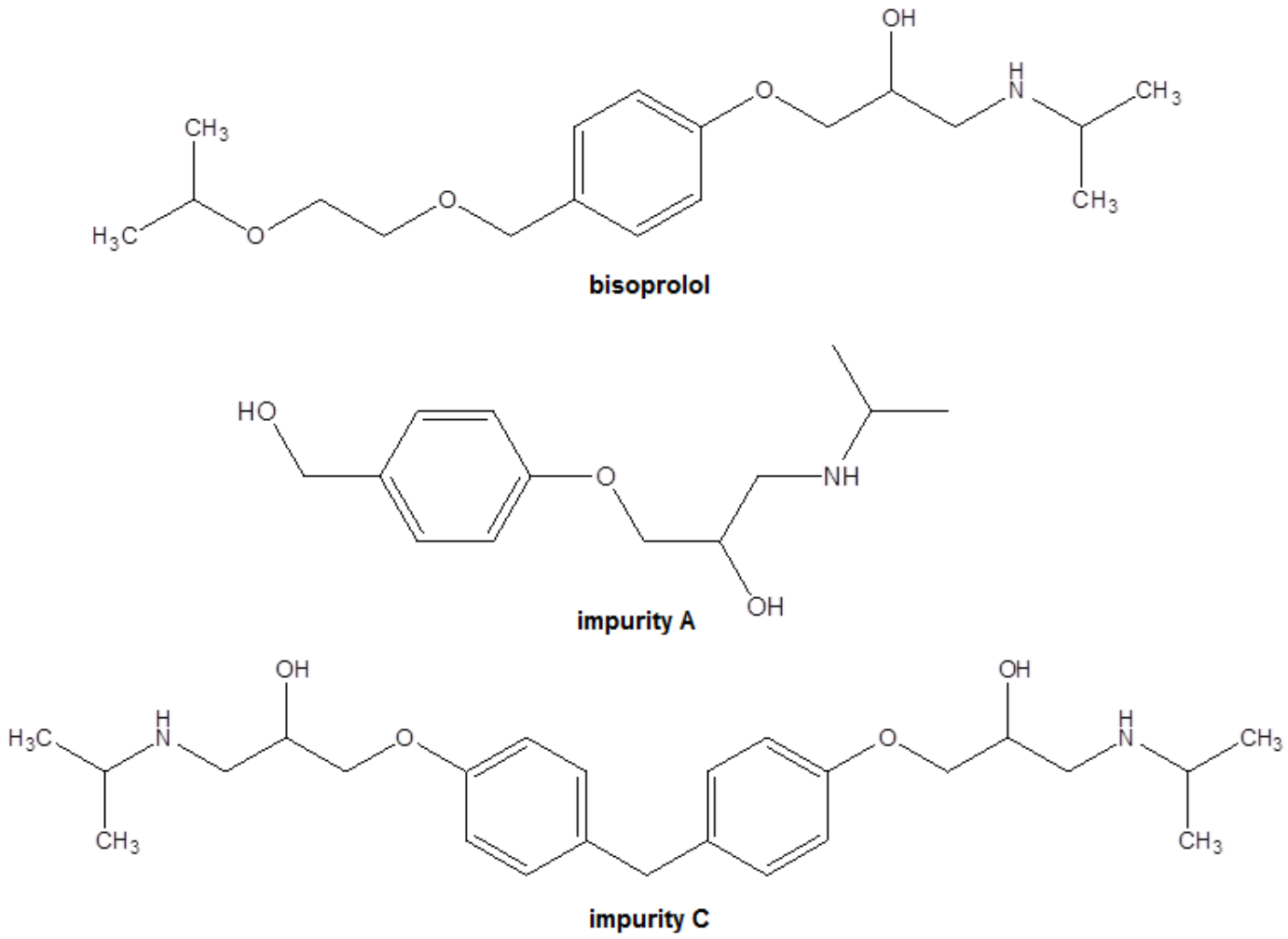

Figure 1. Chemical structure of the investigated substances

\section{Slika 1. Hemijska struktura ispitivanih supstanci}

Literature survey revealed several papers describing the determination of bisoprolol either alone or in combination with other antihypertensive drugs in pharmaceutical dosage forms were found. For determination of bisoprolol alone, spectrophotometric methods [10-11] and chromatographic methods [12] were developed. On the other hand, for drug combinations, HPLC (High Performance Liquid Chromatography)methods were mainly suggested [13-16]. Simultaneous analysis of bisoprololfumarate and hydrochlorothiazide in pharmaceutical dosage forms was carried out by HPTLC (High Performance Thin Layer Liquid Chromatography) [13]. RP-HPLC (Reversed Phased High Performance Liquid Chromatography) methods were developed for simultaneous estimation of bisoprolol fumarate and 
hydrochlorothiazide in tablet formulation [14, 15, 16], and for bisoprolol fumarate and amlodipine besylate in tablets [17]. Also, fully validated simultaneous determination of bisoprolol fumarate and hydrochlorothiazide in their dosage forms using different voltammetric, chromatographic, and spectrophotometric analytical methods was developed [18].The method for the investigation of bisoprolol and impurities is included in European Pharmacopeia 7 [19]. Several papers dealing with HPLC determination of bisoprolol and potential impurities simultaneously were found [20,21].

This paper would be the first one in which HILIC method is applied for the determination of bisoprololfumarate and its impurities. Moreover, this is the first paper where robust optimization of the separation of these analytes was carried out.

\section{Experimental}

\section{Chemicals}

All used reagents were of the analytical grade. The mobile phase and the solvents were prepared from acetonitrile (Lab Scan, Lab Scan, Gliwice, Poland), ammonium acetate (J. T. Backer, Deventer, The Netherlands), glacial acetic acid (Zorka Pharma, Šabac, Serbia), and HPLC grade water (Simplicity 185, Millipore, Germany). Bisoprolol and its impurities were of $\mathrm{Ph}$. Eur quality (obtained from PharmaS, Belgrade, Serbia).

\section{Standard Solutions}

Stock solutions were prepared dissolving the substances in the acetonitrile aqueous phase (30 mM ammonium acetate, $\mathrm{pH} 4.5$ adjusted by acetic acid) $85: 15 \mathrm{v} / \mathrm{v}$, in order to obtain the concentration of $300 \mu \mathrm{g} \mathrm{mL}^{-1}$ for bisoprolol fumarate, $100 \mu \mathrm{g} \mathrm{mL}$ for impurity A and $200 \mu \mathrm{g} \mathrm{mL} \mathrm{m}^{-1}$ for impurity C.

\section{Mobile Phase}

The mobile phase composition was defined as acetonitrile - aqueous phase (with ammonium acetate) where the amount of organic solvent, buffer type and $\mathrm{pH}$ of the aqueous phase were varied according to Box-Behnken experimental plan.

\section{$\underline{\text { Chromatographic conditions }}$}

The experiments were performed on chromatographic system Finnigan Surveyor (Thermo Fisher Scientific, San Jose, CA, USA) consisting of HPLC Pump, Autosampler Plus and UV/VIS Plus Detector. ChromQuest (Thermo Electron, San Jose Operations, San Jose, CA, USA) was used for data collection. The analytical column was Kinetex HILIC $100 \AA$ (100 mm x $4.5 \mathrm{~mm}, 2.6 \mu \mathrm{m}$ particle size), (Phenomenex, 
Torrance, CA, USA). Flow rate was $1 \mathrm{~mL} \mathrm{~min}^{-1}$ and column temperature was $30^{\circ} \mathrm{C}$. UV detection was carried out at $254 \mathrm{~nm}$.

\section{$\underline{\text { Software }}$}

Experimental plan is created in DesignExpert 7.0.0. (Stat-Ease Inc., Minneapolis, MN, USA). Indirect modeling and grid point search optimization were conducted in MATLAB 7.10.0 (Mathworks, Natick, MA, USA).

\section{Results and discussion}

Chemometric approach to LC method development leads to the theoretical explanation of chromatographic system behavior. The first benefit of such strategy is the minimal experimental effort. However, the more important benefit is the ability to resolve complex optimization problems which could hardly be achieved by simple trial and error procedure [1]. Moreover, it can reveal interactions that can not be seen when OFAT (one-factor-at-a-time) strategy is followed. Accordingly, the robust optimization of the method for the analysis of bisoprolol and its impurities was achieved following the main steps of chemometric strategy: 1) Definition of the objectives of the method; 2) Definition of investigated factors and their levels; 3) Selection of appropriate experimental design; 4) Creation of mathematical models; 5) Identification of optimal conditions.

\section{1) Definition of the objectives of the method}

The method development started with the definition of method targets. The maximal separation between all adjacent peaks and the minimal analysis duration are selected as desired goals. Moreover, the located optimum should be robust enough to enable reliable routine application of the method.

2) Definition of investigated factors and their levels

The next phase of the research involved the assessment of the factors that could influence method performances. HILIC system consists of polar stationary phases and mobile phases with high amount or organic solvent (preferably acetonitrile) and small amount of water phase $[8,9]$. The most widely applied columns are bare silica columns. The addition of buffers such as ammonium acetate in water phase is highly recommended since it decreases the electrostatic interaction between ionizableanalyteand silanolgroups at column surface. Therefore, the preliminary investigations of the examined mixture were done using Kinetex HILIC $100 \AA(100 \mathrm{~mm}$ x $4.5 \mathrm{~mm}, 2.6 \mu \mathrm{m}$ particle size) bare silica column and mobile phase consisted of acetonitrile and water phase modified with the addition of ammonium acetate buffer and glacial acetic acid. It is concluded that the mobile phase content strongly influence the retention behavior of the analyzed substances and the following factors are defined as 
potentially significant for detailed investigation in the optimization phase: acetonitrile content in the mobile phase, $\mathrm{pH}$ value of the water phase and ammonium acetate concentration in the water phase. Factors and their levels are presented in Table I.

Table I Investigated factors and their levels

Tabela I Ispitivani faktori i njihovi nivoi

\begin{tabular}{|l|c|c|c|}
\hline \multicolumn{1}{|c|}{ Factor } & \multicolumn{3}{c|}{ Factor level } \\
\hline $\begin{array}{l}\mathbf{x}_{1}-\text { acetonitrile content in the } \\
\text { mobile phase (\%) }\end{array}$ & $82(-1)$ & $85(0)$ & $88(+1)$ \\
\hline $\mathbf{x}_{\mathbf{2}}-\mathbf{p H}$ of the water phase & $3.5(-1)$ & $4.5(0)$ & $5.5(+1)$ \\
\hline $\begin{array}{l}\mathbf{x}_{3}-\text { ammonium acetate } \\
\text { concentration in water phase } \\
(\mathbf{m M})\end{array}$ & $20(-1)$ & $30(0)$ & $40(+1)$ \\
\hline
\end{tabular}

*coded factor levels are presented in brackets

It is decided to evaluate the part of experimental space where acetonitrile content is in the range from $82 \%$ to $88 \%$. The lower organic solvent amount led to the nonretention behavior, while the elution time for the content over $88 \%$ was extremely long. $\mathrm{pH}$ range between 3.5 and 5.5 was acceptable for this column type and it was indicated that the adequate separation of the investigated substances within this range could be found. Ammonium acetate content between 20 mMand $40 \mathrm{mM}$ provided sufficient interaction with stationary phase. In this stage of the research it was decided that column type, column temperature, mobile phase flow rate and wavelength of detection will be kept on constant level during the optimization procedure.

3) Selection of the appropriate experimental design

The LC method optimization by chemometric approach requires the application of response surface designs. These designs enable the investigation of each factor on minimum three levels providing the creation of quadratic dependence of the responses on the selected factors. The most commonly applied designs of this type are central composite design, Box-Behnken design, Doehlert design etc [1]. In this separation problem Box-Behniken design was selected for the creation of experimental plan that is presented in Table II. 
Table II Experimental plan according to Box-Behnken experimental design

Tabela II Plan eksperimenta prema Box-Behnken eksperimentalnom dizajnu

\begin{tabular}{|c|c|c|c|}
\hline $\begin{array}{c}\text { Number of } \\
\text { experiment }\end{array}$ & $\mathbf{x}_{\mathbf{1}}$ & $\mathbf{x}_{\mathbf{2}}$ & $\mathbf{x}_{\mathbf{3}}$ \\
\hline 1 & 82 & 3.5 & 30 \\
\hline 2 & 88 & 3.5 & 30 \\
\hline 3 & 82 & 5.5 & 30 \\
\hline 4 & 88 & 5.5 & 30 \\
\hline 5 & 82 & 4.5 & 20 \\
\hline 6 & 88 & 4.5 & 20 \\
\hline 7 & 82 & 4.5 & 40 \\
\hline 8 & 88 & 4.5 & 40 \\
\hline 9 & 85 & 3.5 & 20 \\
\hline 10 & 85 & 5.5 & 20 \\
\hline 11 & 85 & 3.5 & 40 \\
\hline 12 & 85 & 5.5 & 40 \\
\hline 13 & 85 & 4.5 & 30 \\
\hline 14 & 85 & 4.5 & 30 \\
\hline 15 & 85 & 4.5 & 30 \\
\hline
\end{tabular}

${ }^{*} \mathrm{x}_{1}-$ acetonitrile content $(\%)$ in the mobile phase; $\mathrm{x}_{2}-\mathrm{pH}$ of the water phase;

$\mathrm{x}_{3}-$ ammonium acetate concentration $(\mathrm{mM})$ in the water phase

Box-Behnken design requires lower number of experiments than central composite design and it is suitable for experimental problems where extreme factor combinations are undesirable. Doehlert design enables the estimation of some factors on more than three levels, however, in presented study this feature was not of interest.

The experiments are performed randomly and in each run retention times of the beginning, apex and the end of each peak are recorded.

4) Creation of mathematical models

There is a great number of chromatographic responses that are relevant for the understanding of systems behavior. By applying Box-Behnken and other response surface designs the following relationship between factors and responses can be obtained:

$$
Y=b_{0}+\sum_{i=1}^{N} b_{i} X_{i}+\sum_{i=1}^{N} \sum_{j=1}^{N} b_{i j} X_{i j}
$$


where $\mathrm{Y}$ is the response; $\mathrm{b}_{0}, \mathrm{~b}_{\mathrm{i}}, \mathrm{b}_{\mathrm{ij}}$, $\mathrm{b}_{\mathrm{ii}}$ correspond to the intercept, linear, interaction and quadratic term coefficients, respectively.

However, in modern literature the direct mathematical modeling is not recommended for all outputs [22]. There is agreatprobability that quadratic function will fail to describe complex responses (such as resolution factor) accurately.On the other hand, the modeling of simple responses such as retention times and retention factors is straightforward and there is a greater probability that second order polynomial model will satisfactorily explain its behavior. Therefore, in this paper the direct modeling is performed for the retention factors of investigated substances in order to examine their chromatographic behavior but also for the retention times of the beginning and the end of each peak since these two retention times will be used for a posteriori calculation of separation criterion. The obtained models and statistical parameters are presented in Table III.

Table III The obtained mathematical models for the investigated responses

Tabela III Dobijeni matematički modeli za ispitivane odgovore

\begin{tabular}{|c|c|c|c|c|c|c|c|c|c|}
\hline & $\mathbf{B t}_{\mathrm{b}}$ & $\mathbf{B k}_{\mathrm{a}}$ & $\mathbf{B t}_{\mathrm{e}}$ & $\mathbf{C t}_{\mathrm{b}}$ & $\mathbf{C k}_{\mathrm{a}}$ & $\mathbf{C t}_{\mathrm{e}}$ & $\mathbf{A t}_{\mathrm{b}}$ & $\mathbf{A} \mathbf{k}_{\mathrm{a}}$ & $\mathbf{A t}_{\mathrm{e}}$ \\
\hline $\mathbf{b}_{0}$ & 3.24 & 2.87 & 3.56 & 3.92 & 3.61 & 4.18 & 4.44 & 4.25 & 4.74 \\
\hline$b_{1}$ & 1.09 & 1.27 & 1.19 & 1.40 & 1.63 & 1.45 & 1.69 & 1.99 & 1.78 \\
\hline $\mathbf{b}_{2}$ & 0.54 & 0.69 & 0.64 & 0.78 & 0.93 & 0.93 & 0.99 & 1.18 & 1.11 \\
\hline $\mathbf{b}_{3}$ & -0.46 & -0.51 & -0.46 & -0.53 & -0.60 & -0.60 & -0.55 & -0.65 & -0.57 \\
\hline $\mathbf{b}_{12}$ & 0.13 & 0.14 & 0.14 & 0.16 & 0.16 & 0.11 & 0.24 & 0.28 & 0.28 \\
\hline $\mathbf{b}_{13}$ & -0.17 & -0.24 & -0.23 & -0.23 & -0.30 & -0.26 & -0.26 & -0.32 & -0.30 \\
\hline $\mathbf{b}_{23}$ & -0.19 & -0.25 & -0.23 & -0.30 & -0.31 & -0.36 & -0.32 & -0.37 & -0.30 \\
\hline$b_{11}$ & 0.29 & 0.38 & 0.36 & 0.37 & 0.47 & 0.44 & 0.52 & 0.61 & 0.53 \\
\hline$b_{22}$ & 0.11 & 0.19 & 0.16 & 0.16 & 0.21 & 0.28 & 0.24 & 0.29 & 0.32 \\
\hline $\mathbf{b}_{33}$ & 0.02 & 0.02 & 0.01 & 0.03 & 0.04 & 0.05 & 0.03 & 0.03 & 0.05 \\
\hline $\mathbf{R}^{2}$ & 0.999 & 0.998 & 0.998 & 0.998 & 0.997 & 0.998 & 0.999 & 0.998 & 0.998 \\
\hline Adj. $\mathbf{R}^{2}$ & 0.997 & 0.995 & 0.996 & 0.994 & 0.992 & 0.993 & 0.996 & 0.995 & 0.995 \\
\hline Pred. $\mathbf{R}^{2}$ & 0.989 & 0.979 & 0.984 & 0.970 & 0.962 & 0.968 & 0.980 & 0.980 & 0.981 \\
\hline $\begin{array}{l}\text { Lack of fit } \\
\text { (p-value) }\end{array}$ & 0.573 & 0.458 & 0.552 & 0.332 & 0.283 & 0.339 & 0.318 & 0.408 & 0.462 \\
\hline
\end{tabular}


$* \mathrm{~b}_{0}-\mathrm{b}_{33}$ - the model coefficients; $\mathrm{Bt}_{\mathrm{b}} \cdot \mathrm{Bt}_{\mathrm{e}}$ - the retention time of the beginning and the end of bisoprolol peak; $\mathrm{Ct}_{\mathrm{b}}$. $\mathrm{Ct}_{\mathrm{e}}$ - the retention time of the beginning and the end of impurity $\mathrm{C}$ peak; $\mathrm{At}_{\mathrm{b}}$. $\mathrm{At}_{\mathrm{e}}$ - the retention time of the beginning and the end of impurity A peak; $\mathrm{Bk}_{\mathrm{a}}, \mathrm{Ck}_{\mathrm{a}}, \mathrm{Ak}_{\mathrm{a}}$ - retention factor of bisoprolol, impurity $\mathrm{C}$ and impurity $\mathrm{A}$, respectively; $\mathrm{R}^{2}$ - coefficient of determination, Adj. $\mathrm{R}^{2}$ - Adjusted coefficient of determination, Pred. $\mathrm{R}^{2}$ - Predicted coefficient of determination

The obtained values of coefficient of determination $\left(R^{2}\right)$, adjusted coefficient of determination (Adj. $R^{2}$ ) and predicted coefficient of determination (Pred. $R^{2}$ ) indicate that models succeeded in describing the analyzed responses with high statistical reliability. Moreover, p-values obtained for lack of fit test are all grated than 0.05 suggesting that there was no significant lack of fit.

Analyzing the results obtained in Table III the conclusions about retention behavior of the investigated analytes can be drawn. As it is already wide known, the retention of the different types of compounds in HILIC can be driven by various processes in the retention mechanism (eg. partition, adsorption and/or electrostatic interactions). The involvement of each process in the overall HILIC retention mechanism depends on three groups of factors [8]: 1) surface characteristics of the stationary phase; 2) structural properties of the analyzed compounds and 3) mobile phase composition.

The created second-order polynomial models for each analyte were not only useful in the prediction of their retention within the examined experimental space, but they also enabled in-depth description of their retention behavior in the given HILIC system. Namely, on the basis of the absolute values and the signs of the coefficients of the obtained models the influence of all the examined factors of the mobile phase, as well as their interactions, on the analytes' retention could be determined. Furthermore, this approach also provided an insight into HILIC retention mechanism controlling the retention of bisoprolol and its impurities.

Regarding the coefficients of the obtained quadratic models presented in Table III thorough description of the influence of mobile phase factors on the retention behavior of the analyzed compounds is given below. The absolute value of the coefficient characterizes the magnitude of the effect, whereas the sign of the coefficient shows whether the increase of the factor value increases ("+" sign) or decreases ("-" sign) the retention. Since the coefficients that were statistically significant $(p<0.05)$ entered the final retention models, only they were taken into account while considering the factor influences. On the basis of the coefficients $b_{1}, b_{2}$ and $b_{3}$ influences of acetonitrile content in the mobile phase, $\mathrm{pH}$ of the water phase and concentration of ammonium acetate in the water phase on the analytes' retention were estimated, respectively. 
Comparing the absolute values of these coefficients in all the models it can be deduced that acetonitrile content in the mobile phase exhibited the strongest influence on the retention of all the compounds, $\mathrm{pH}$ of the water phase showed weaker influence, whereas ammonium acetate concentration in the water phase weakest influence. Positive sign of $b_{1}$ coefficients implies that the increase of acetonitrile content in the mobile phase led to the increasing of the analytes' retention. This behavior is expected, since less polar mobile phases in HILIC systems have lower elution strength, thereby extending the retention time of polar analytes.In the current research bare silica column was utilized. According to the findings in the literature the surface of this type of HILIC columns is mainly negatively charged when $\mathrm{pH}$ of the mobile phase is greater than 4.0 due to the presence of free silanol groups $(\mathrm{pKa} \approx 4.0)$ [9]. Therefore, in the examined range of the $\mathrm{pH}$ of the mobile phase $(3.5-5.5)$, the number of the ionized silanol groups will increase with the increasing $\mathrm{pH}$ of the mobile phase. Bisoprolol and its impurities possess secondary amino group in their structures. These groups are strongly basic, thus, it is expected that they will be in their protonated form within the examined $\mathrm{pH}$ range of the mobile phase. Provided that direct electrostatic interaction between the oppositely charged groups between these analytes and column surface exist, it can be expected that their retention will increase with the increasing $\mathrm{pH}$ of the mobile phase as a consequence of the increased influence of the ion-exchange process in the retention mechanism. Positive sign of $b_{2}$ coefficients evidences the increase of the analytes' retention with the increasing $\mathrm{pH}$ of the water phase, therefore the existence of ionexchange process in the retention mechanism was confirmed. Regarding that on the basis of the structural properties of the analyzed compounds and surface characteristics of a silica column this process was expected to be involved in the retention mechanism, buffer salt (ammonium acetate) was also the part of a mobile phase. The aim was to decrease the strong influence of electrostatic forces between the analytes by neutralizing the charge on the column surface and preventing excess retention accordingly. Negative sign of $b_{3}$ coefficients in created models shows that the increase of the concentration of ammonium acetate in the water phase led to weaker retention. Thus, previously suggested retention mechanism was confirmed. Furthermore, statistically significant $\mathrm{b}_{1}{ }^{2}$ and $\mathrm{b}_{2}{ }^{2}$ coefficients in the established models suggest nonlinear dependence of the analytes' retention on acetonitrile content in the mobile phase and $\mathrm{pH}$ of the water phase, respectively.

The assessment of the simultaneous influence of the examined factors on the analytes' retention behavior was based on interaction coefficients $b_{12}, b_{13}$ and $b_{23}$. In order to facilitate the visualization of factor interactions 3D response surface plots are presented in Figure 2. 
A)

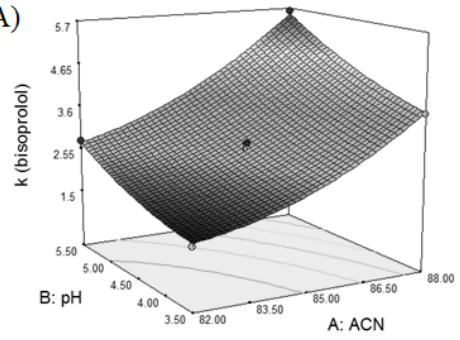

B)

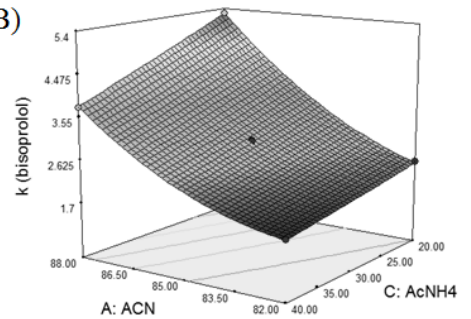

C)

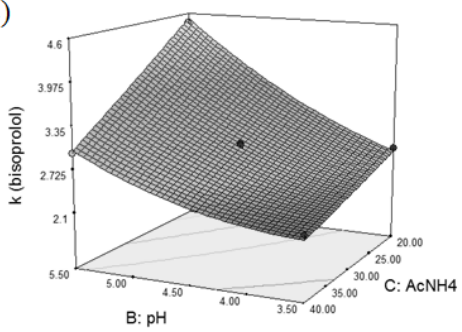

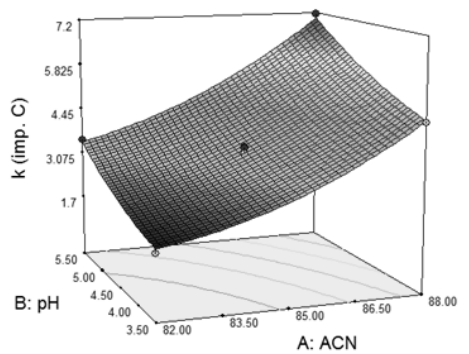
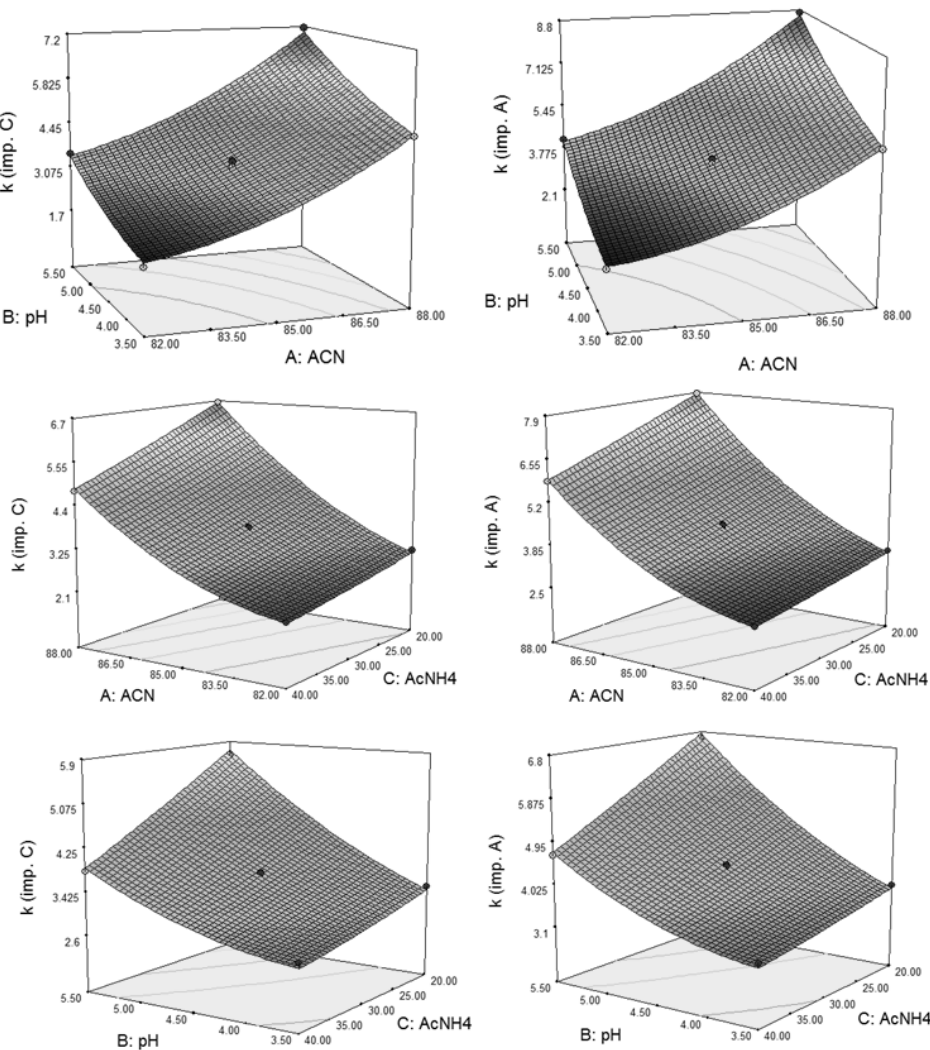

Figure 2. 3D response surfaces obtained for retention factors of the investigated substances presenting their dependence on $\mathrm{A}$ ) acetonitrile content ( $\mathrm{ACN}$ ) and $\mathbf{p H}$ of the water phase (pH); B) acetonitrile content and ammonium acetate concentration in water phase $\left(\mathrm{AcNH}_{4}\right)$; $\left.\mathrm{C}\right) \mathrm{pH}$ of the water phase and ammonium acetate concentration in water phase

Slika 2. 3D površine odgovora dobijene za retencione faktore ispitivanih supstanci koje predstavljaju njihovu zavisnost od A) sadržaja acetonitrilau mobilnoj fazi (ACN) i pH vrednosti vodene faze (pH); B) sadržaja acetonitrila u mobilnoj fazi i koncentracije amonijum-acetata u vodenoj fazi $\left(\mathrm{AcNH}_{4}\right)$; $\left.\mathrm{C}\right) \mathrm{pH}$ vrednosti vodene faze i koncentracije amonijum-acetata u vodenoj fazi

Positive sign of $b_{12}$ coefficients implies that simultaneous increase of acetonitrile content in the mobile phase and $\mathrm{pH}$ of the water phase enhances the retention (Figure $2 A)$. On the other hand, negative sign of $b_{13}$ and $b_{23}$ coefficients evidence that the simultaneous increase of acetonitrile content in the mobile phase and decrease of ammonium acetate in the water phase (Figure 2B), as well as increase of $\mathrm{pH}$ of the water phase and decrease of concentration of ammonium acetate in the water phase (Figure 2C), respectively, tend to prolong the retention. 


\section{5) Identification of optimal conditions}

The optimization goal for the investigated system was robust and adequate separation within minimal analysis duration. The quality of separation of adjacent peak pairs was measured by separation criterion $s$ which is equal to the difference between the retention time of the beginning of the second peak and the retention time of the end of the first peak [23]. The value of $S$ criterion that is greater than 0 indicates that the complete baseline separation of the peak pair is achieved. $S$ criterion has advantages comparing to the other traditionally applied separation criteria such as selectivity factor or resolution factor. Namely, the optimal value of both selectivity and resolution factors are influenced by the peak widths and the analyst should decide which value of these factors is high enough for complete separation. On the other hand, $S$ criterion is not influenced by the peak width and therefore the adequate value of the criterion is not arbitrary.

Accordingly, in this optimization problem the achievement of $S$ values greater than 0 for all adjacent peak pairs was set as prior goal. Additionally, during the experimental procedure the interfering peak of fumaric acid appeared. Thus, the separation of this peak from the analyzed substances was considered as well. The secondary optimization goal was the achievement of the minimal analysis duration which was measured as the retention time of the end of the last eluting peak.

Grid point search methodology was applied for the identification of optimal conditions. The experimental space was divided with a grid containing 7 levels for acetonitrile content in the mobile phase (the increment of $1 \%$ ), 11 levels for $\mathrm{pH}$ of the water phase (the increment of $0.2 \mathrm{pH}$ units) and 5 levels for buffer concentration in the water phase (the increment of $5 \mathrm{mM}$ ). The theoretical values of separation criterions and analysis duration are calculated in defined 385 grid points. The optimization procedure intended to locate the point where all $S$ criteria are greater than 0 and where the total analysis duration is less than 10 minutes. However, the accuracy of theoretical investigation of the experimental space is completely dependent on the adequacy of created mathematical models. Therefore, the incertitude originating from the models leads to the uncertainty in accurate location of optimal point. If the uncertainty of mathematical model is not considered, there is no guarantee that the $s$ criterion will achieve calculated value with high probability $[5,6,22]$. In this study the problem of responses uncertainty was overcome by creation of oversized chromatograms [5].The uncertainties in retention time associated with the predictions achieved with the retention model are presented as an extra band broadening for each chromatographic peak corresponding to the value of standard deviation. After the peaks enlargement, for each of 385 points the new values for the beginning and the end of each peak are calculated and $S$ values and total analysis duration are estimated. Applying the robust optimization strategy, there is a probability of $95 \%$ that the newly obtained responses 
will be accurate. The optimal point having the satisfactory value for all targets is defined with the following values of examined factors: acetonitrile content $85 \%$; $\mathrm{pH}$ value of the water phase 4.9 and ammonium acetate concentration $35 \mathrm{mM}$.

In the final stage of the research, additional source of the optimum instability the one originating from the adjustment of factors values during the routine experimental procedure - is assessed. The theoretical robustness testing is performed applying $2^{3}$ full factorial design. The same three factors included in optimization phase are investigated;however, the factors levels are narrowed down according to the expected experimental variation. The experimental plan is presented in Table IV.

Table IV The experimental plan for the robustness study

Tabela IV Eksperimentalni plan za testiranje robusnosti

\begin{tabular}{|c|c|c|c|c|c|c|}
\hline $\begin{array}{c}\text { Number of } \\
\text { experiment }\end{array}$ & ACN & $\mathbf{p H}$ & $\mathbf{A c N H}_{\mathbf{4}}$ & $\mathbf{s}_{\mathbf{1}}$ & $\mathbf{s}_{\mathbf{2}}$ & $\mathbf{s}_{\mathbf{3}}$ \\
\hline 1 & 84 & 4.8 & 33 & 0.280 & 0.228 & 2.662 \\
\hline 2 & 86 & 4.8 & 33 & 0.310 & 0.212 & 1.855 \\
\hline 3 & 84 & 5.0 & 33 & 0.332 & 0.212 & 1.560 \\
\hline 4 & 86 & 5.0 & 33 & 0.477 & 0.411 & 5.198 \\
\hline 5 & 84 & 4.8 & 37 & 0.451 & 0.439 & 6.464 \\
\hline 6 & 86 & 4.8 & 37 & 0.423 & 0.409 & 6.511 \\
\hline 7 & 84 & 5.0 & 37 & 0.297 & 0.232 & 2.425 \\
\hline 8 & 86 & 5.0 & 37 & 0.441 & 0.430 & 6.534 \\
\hline
\end{tabular}

*ACN - acetonitrile content in the mobile phase (\%); $\mathrm{pH}-\mathrm{pH}$ of the water phase; AcNH4 - ammonium acetate concentration in the water phase $(\mathrm{mM}) ; \mathrm{s}_{1}$ - separation criterion for bisoprolol and impurity $\mathrm{A} ; \mathrm{s}_{2}-$ separation criterion for impurity $\mathrm{A}$ and impurity $\mathrm{C} ; \mathrm{s}_{3}-$ separation criterion for impurity $\mathrm{C}$ and fumaric acid

The obtained values for all separation criteria $S$ are presented in Table IV, as well. Analyzing the obtained values it can be concluded that the defined optimal point will preserve the desired quality even if the slight deviation of examined factors occurs. Unlike the traditionally single factor at the time robustness testing where the response is exposed to the variation of one factor, the experimental design approach examine the response behavior when several (and all) factors deviate at the same time. The other strategy corresponds more to what can be expected in the practice and therefore the obtained results indicate higher assurance of optimum quality. 
Finally, the experimental chromatographic verification (Figure 3) confirmed that the applied robust optimization succeeded to identify reliable optimum.

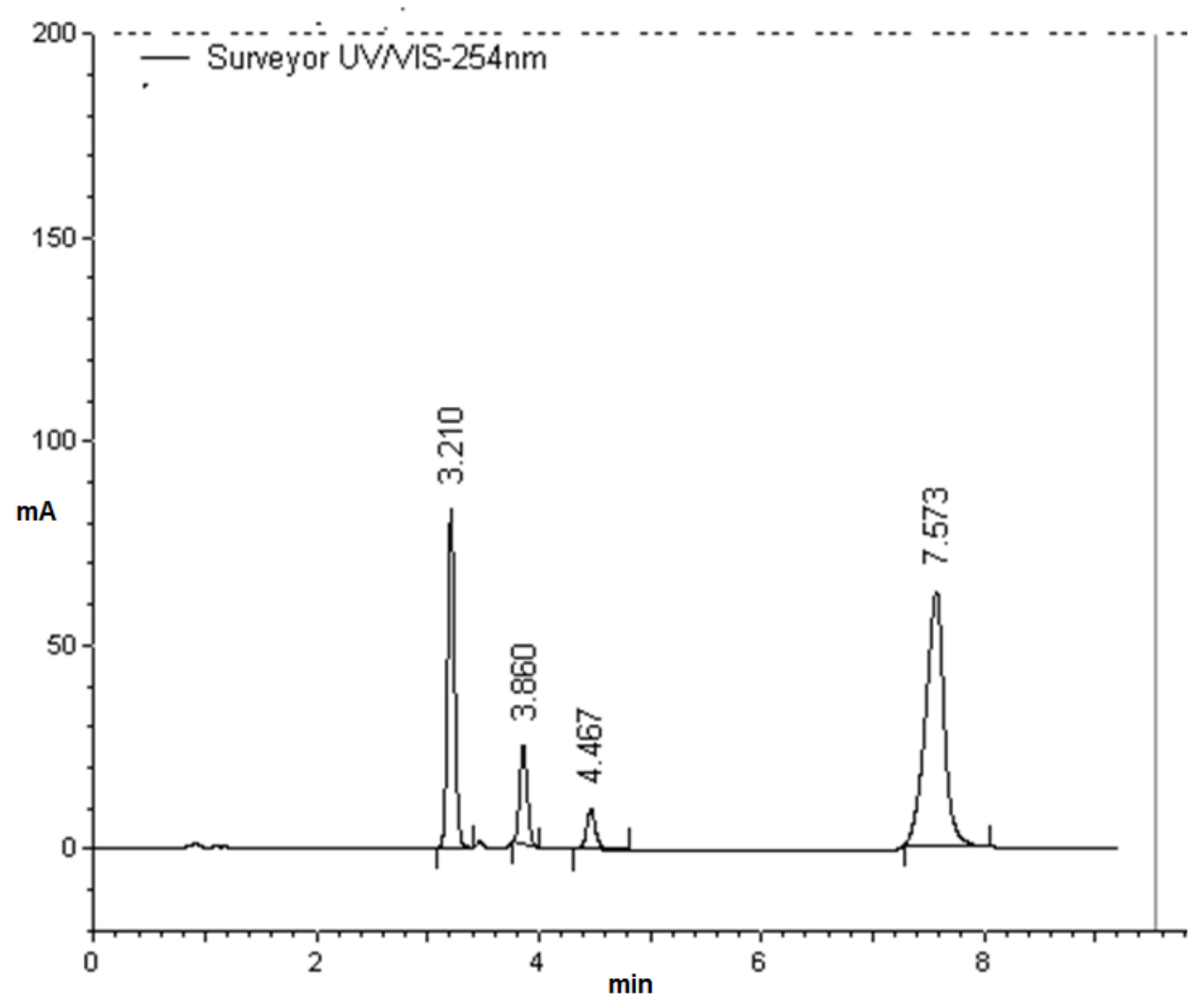

Figure 3. The experimentally obtained chromatogram under the optimal conditions: chromatographic column Kinetex HILIC 100Å $(100 \mathrm{~mm}$ x $4.5 \mathrm{~mm}, 2.6 \mu \mathrm{m}$ particle size); mobile phase composed of acetonitrile - water phase (35 $\mathrm{mM}$ ammonium acetate, $\mathrm{pH} 4.9$ adjusted with glacial acetic acid) $(85: 15 \mathrm{v} / \mathrm{v})$; flow rate $1 \mathrm{~mL} \mathrm{~min}^{-1}$, column temperature $30^{\circ} \mathrm{C}$ and $\mathrm{UV}$ detection at $254 \mathrm{~nm}$; elution order of substances: bisoprolol $(\operatorname{tr}=\mathbf{3 . 2 1 0} \mathrm{min})$; impurity $\mathrm{C}(\mathrm{tr}=\mathbf{3 . 8 6 0} \mathrm{min})$; impurity $A(\operatorname{tr}=4.467 \mathrm{~min})$; fumaric $\operatorname{acid}(\mathrm{tr}=7.573 \mathrm{~min})$

Slika 3. Eksperimentalno dobijeni hromatogram pod optimalnim uslovima: hromatografska kolona Kinetex HILIC $100 \AA$ (100 mm x 4,5 mm, veličina čestica 2,6 $\mu \mathrm{m})$; mobilna faza: acetonitril - vodena faza (35 $\mathrm{mM}$ amonijum-acetat, $\mathbf{p H}$ podešen na 4,9 glacijalnom sirćetnom kiselinom) $(85: 15 \mathrm{v} / \mathrm{v})$; protok mobilne faze

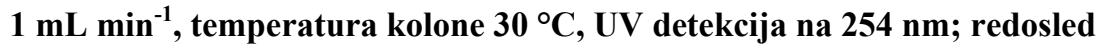
eluiranja supstanci: bisoprolol $(\operatorname{tr}=3,210 \mathrm{~min})$; nečistoća $\mathrm{C}(\operatorname{tr}=3,860 \mathrm{~min})$; nečistoća A (tr = 4,467 min); fumarna kiselina ( $\operatorname{tr}=7,573 \mathrm{~min})$ 


\section{Conclusion}

This paper presented step by step application of chemometric approach in robust optimization of HILIC method for separation of bisoprolol and its impurities. The theoretical models describing the retention behavior of the analyzed substances are established and their statistical adequacy is confirmed. Models are successfully applied for experimental space navigation and identification of optimal points in terms of satisfactory separation quality and analysis duration. The optimum proved to be robust enough in terms of two sources of potential incertitude: the one originating from theuncertainty in mathematical model and the other originating from the variability in adjustment of process parameters.

Acknowledgements The authors thank the Ministry of Education, Science and Technological Development of the Republic of Serbia for supporting these investigations in Project 172052.

\section{References}

1. Cela R, Ordonez EY, Quintana JB, Rodil R. Chemometric-assisted method development in reversed-phase liquid chromatography. J Chromatogr A. 2013;1287:2-22.

2. International Conference on Harmonization (ICH) of Technical Requirements for Registration of Pharmaceuticals for Human Use, Topic Q8 (R2): Pharmaceutical Development, ICH, Geneva, Switzerland, 2009.

3. International Conference on Harmonization ( $\mathrm{ICH})$ of Technical Requirements for Registration of Pharmaceuticals for Human Use, Topic Q9 : Quality Risk Management, ICH, Geneva, Switzerland, 2005.

4. International Conference on Harmonization ( $\mathrm{ICH})$ of Technical Requirements for Registration of Pharmaceuticals for Human Use, Topic Q10: Pharmaceutical quality System, ICH, Geneva, Switzerland, 2008.

5. Vivo-Truyols G, Concha-Herrera V, Torres-LapasioJR, Garcia-Alvarez-Coque MC.Robust interpretive optimisation in high-performance liquid chromatography considering uncertainties in peak position. J Chromatogr A. 2005;1096:123-32.

6. Rozet E, Lebrun P, Debrus B, Boulanger P, Hubert Ph.Design Space for analytical methods. TRAC-Trend Anal Chem. 2013; 42:157-67.

7. Orlandini S, Pinzauti S, Furulanetto S. Application of quality by design to the development of analytical separation methods.Anal Bioanal Chem. 2013; 405:443-50.

8. JanderaP. Stationary and mobile phases in hydrophilic interaction chromatography: a review. Anal Chim Acta. 2011;692: 1-25.

9. Greco G,Letzel T. Main interactions and influences of the chromatographic parameters in HILIC separations. JChromatogr Sci. 2013; 51:684-93. 
10. Ulu ST, Kel E. Spectrophotometric determination of bisoprolol in pharmaceutical preparations by charge transfer reactions. Opt Spektrosk. 2012;112:864-7.

11. Kumbhar ST, Shinde PP, Shinde DB, Solankar PB.Visible spectrophotometric method for estimation of bisoprolol from its bulk and tablet formulation.Asian J Pharm Clin Res. 2013; 6:103-5.

12. Arjun G, Sathis KD, Bindu MB, Naga MM, Ramalingam R, RavinderNath A. A simple HPLC method for quantitation of bisoprolol fumarate in tablet dosage form. Indian Drugs. 2009;46:3942.

13. Yadav SS, Rao JR. Simultaneous HPTLC analysis of bisoprolol fumarate and hydrochlorthiazide in pharmaceutical dosage form. Int J Pharm Pharm Sci. 2013;5:286-90.

14. Joshi SJ, Karbhari PA, Bhoir SI, Bindu KS, Das C. RP-HPLC method for simultaneous estimation of bisoprolol fumarate and hydrochlorothiazide in tablet formulation. $\mathrm{J}$ Pharm Biomed Anal.2010;52:362-71.

15. Shaikh S, Thusleem OA., Muneera MS, Akmal J, Kondaguli AV, Ruckmani K. A simple and rapid high-performance liquid chromatographic method for the determination of bisoprolol fumarate and hydrochlorothiazide in a tablet dosage form.J Pharm Biomed Anal. 2008;48(3):1055-7.

16. Patel LJ,Suhagia BN,Shah PB,Shah RR. Simultaneous estimation of bisoprololfumarate and hydrochlorothiazide in tablet dosage form by RP-HPLC method.Indian J Pharm Sci. 2006;68:635-8

17. Vora D, Kadav A. Development and validation of a simultaneous HPLC method for estimation of bisoprolol fumarate and amlodipine besylate from tablets. Indian J Pharm Sci. 2008; 70:542-6.

18. Bozal B, Gumustas M, Dogan-Topal B, Uslu B, Ozkan SA.Fully validated simultaneous determination of bisoprololfumarate and hydrochlorothiazide in their dosage forms using different voltammetric, chromatographic, and spectrophotometric analytical methods.J AOAC International.2013; 96:42-51.

19. European Pharmacopoeia, $7^{\text {th }}$ edition, 2011, European Directorate for the Quality of Medicines and Healthcare, Council of Europe, Strasbourg.

20. Agapova NN, Vasileva E. High-performance liquid chromatographic method for the determination of bisoprolol and potential impurities. J Chromatogr. 1993; 654:299-302.

21. Szalka M, Kostka J, Rokaszewski E, Kacymarski K. Analysis of related substances in bisoprolol fumarate on sub-2- $\mu \mathrm{m}$ adsorbents. Acta Chromatogr. 2012;24:163-83.

22. Lebrun P, Govaerts B, Debrus B, Ceccato A, Caliaro G, Hubert P, Boulanger B. Development of a new predictive modelling technique to find with confidence equivalence zone and design space of chromatographic analytical methods. Chemometr Intell Lab Syst. 2008;9:4-16.

23. Debrus B, Lebrun P, MbinzeKindenge J,Lecomte F, Ceccato A, Caliaro G, MavarTayeyMbay J, Boulanger B, Marini RD, Rozet E, Hubert Ph. Innovative high-performance liquid chromatography method development for the screening of 19 antimalarial drugs based on a generic approach, using design of experiments, independent component analysis and design space. J Chromatogr A. 2011;1218:5205-15. 


\title{
Optimizacija HILIC metode za analizu bisoprolola i njegovih nečistoća uz procenu mogućnosti variranja položaja pikova
}

\section{Tijana Rakić ${ }^{1 *}$, Marko Jovanović ${ }^{1}$, Anja Tumpa ${ }^{1}$, Biljana Jančić-Stojanović ${ }^{\text {, }}$ Mirjana Medenica ${ }^{2}$}

\author{
${ }^{1}$ Univerzitet u Beogradu - Farmaceutski fakultet, Katedra za analitiku lekova, \\ Vojvode Stepe 450, Beograd, Srbija \\ ${ }^{2}$ Univerzitet u Beogradu - Farmaceutski fakultet, Katedra za fizičku hemiju i \\ instrumentalne metode, Vojvode Stepe 450, Beograd, Srbija
}

\section{Kratak sadržaj}

U ovom radu prikazana je optimizacija metode tečne hromatografije hidrofilnih interakcija za analizu bisoprolola i njegovih nečistoća A i C uz procenu mogućnosti variranja položaja pikova. Primenjena je hemometrijska strategija za detaljno razumevanje ponašanja sistema i uspostavljanje matematičke veze između ispitivanih faktora (sadržaj acetonitrila $u$ mobilnoj fazi, $\mathrm{pH}$ vrednost vodene faze i koncentracija pufera u vodenoj fazi) $\mathrm{i}$ hromatografskih odgovora.

Enumerativna tehnika optimizacije upotrebljena je za identifikaciju tačke koja pokazuje zadovoljavajući kvalitet razdvajanja svih ispitivanih supstanci i minimalno vreme trajanja analize. Kreirani su prošireni hromatogrami širenjem pikova svih ispitivanih supstanci za vrednosti standardne devijacije kako bi se procenila mogućnost greške odgovora koja potiče iz greške matematičkog modela. Mogućnost greške koja potiče iz greške u podešavanju eksperimentalnih parametara procenjena je simuliranim testiranjem robusnosti primenom eksperimentalnog dizajna. Konačno, dobijeni optimalni uslovi bili su: hromatografska kolona Kinetex HILIC $100 \AA$ (100 mm x 4,5 mm, 2,6 $\mu \mathrm{m}$ veličina čestica); mobilna faza sastavljena od smeše acetonitril - vodena faza (35 mM amonijum-acetat, $\mathrm{pH} 4,9$ podešen glacijalnom sirćetnom kiselinom) $(85: 15 \mathrm{v} / \mathrm{v})$; protok $1 \mathrm{~mL} \mathrm{~min}^{-1}$, temperatura kolone $30^{\circ} \mathrm{C}$ i UV detekcija na $254 \mathrm{~nm}$.

Ključne reči: robusnost, HILIC, bisoprolol, nečistoće 